\title{
Quality Control Design on Customized Mica Packaging Craft Product
}

\author{
Agustine Eva Maria Soekesi \\ Soegijapranata Catholic University \\ evamaria@unika.ac.id \\ Veronica Kusdiartini \\ Soegijapranata Catholic University \\ vero@unika.ac.id \\ Meniek Srining Prapti \\ Soegijapranata Catholic University \\ menik@unika.ac.id \\ Bayu Prestyanto \\ Soegijapranata Catholic University \\ bayu@unika.ac.id
}

\begin{abstract}
Quality is one of differentiation strategies that can be addressed to achieve competitive advantage. Many alternatives can be selected to achieve this purpose. One of them is to maintain good quality of the products. A craft souvenir enterprise in Semarang controls the operation system of every product it produces to meet a good quality. This is very important since it produces customized products in which each product is designed according to customer order. A case study was conducted on the mica packaging craft product. Observations for 3 months with weekly production period show that the proportion of defective products is still relatively high compared to that is set by the enterprise (3.6\% against 3\%). By using the Statistical Process Control method and follow-up using the fishbone diagram method, it is found that there are 3 main causes, namely material, man (labor), and machine factors. Refer to this analysis, corrective actions is carried out to reduce occurrence of defective products in the next production periods.
\end{abstract}

Keywords: quality control, statistical process control, defective product, fishbone diagram

\section{INTRODUCTION}

The competition in industry can encourage company managers to try to improve the quality of their products. The aim is to prevent occurrence of damaged products in every production activity. Quality improvement efforts can be done with quality control method. Some of the benefits for the company when conducting quality control include quality 
awareness, customer satisfaction, cost reduction and resource utilization. It also improves reliability, increases productivity and customer satisfaction (Moch, 2009).

According to Prawirosentono (2007) there are three reasons for producing quality products. Consumers who buy products based on quality generally have greater product loyalty than consumers who buy products based on price orientation. Contradicting to the traditional business mindset, it turns out that producing quality goods is not automatically more expensive than producing low quality products. Selling bad quality goods is likely to receive a lot of complaints and returns from consumers.

There are several tools that can be used to control quality, such as the Statistical Process Control (SPC) method. To find out the root causes of defective products, Ishikawa diagrams/Fishbone diagrams/Cause and Effect diagrams can be used. The benefits of the Statistical Process Control (SPC) method and Ishikawa Diagram/Fishbone diagram/Cause and Effect diagram are the basic tools used to solve production problems, especially those related to quality (Kho, 2018).

It is very important for enterprises that make products based on order to maintain and improve the quality of their products. This is because these products are customized, so customer satisfaction must be strictly maintained. This paper examines quality control of souvenir enterprise located in Semarang with 20 years of experience. The enterprise produces souvenir products with various designs and shapes which are made to order. Although each type of product has already a standard platform, several other attributes are tailored to consumer orders.

So far, in every production period, defects are found with an average range of 1 to $3 \%$. The enterprise tries to reduce the percentage of defective products. The study particularly 
focused on craft made from mica plastic since it is the product that is ordered relatively often by customers. Thus the quality of the product is very important to be awarded.

Focusing on defective products that must be followed up is very important to know the causes of product discrepancies. Thus, efforts to overcome defective products will be more effective. This article addresses the efforts made by the enterprise in planning product quality control measurements so that the occurrence of defective products can be reduced.

\section{LITERTURE REVIEW}

\section{Quality Control}

According to Assauri (2008), quality control is an activity to ascertain whether policies in terms of quality/standards can be reflected in the final result. Quality control is an effort to maintain the quality of the goods produced in accordance with the product specifications that have been determined based on the policy of the company leadership. Meanwhile, according to Kaoru Ishikawa, quality control is an activity of researching, developing, designing and fulfilling customer satisfaction, providing good service where the implementation involves all activities within the company from top leaders to executive employees.

To conduct the quality control in operation system, it will be better if the company prepare the quality system document. According to Putri et al (2016) there are three stages can be implemented: evaluation of initial condition, formulation of requirement document, and preparation of document.

Refer to the theory above, a common thread can be drawn that quality control is a control, research, development, and design of the quality of a product to meet consumer satisfaction with the product, where this task applies to all employees, as a form of awareness of the importance of quality a product. 


\section{Statistical Process Control (SPC)}

Gasperz (1998) mentioned Statistical Process Control (SPC) is a term that has been used since the 1970s. It is used to describe the use of statistical techniques in monitoring and producing quality products. In other words, SPC is a process used to monitor standards, make measurements and take corrective actions on a product or service that is being produced. Heizer and Render (2009) also state that SPC can be defined as a general statistical technique used to ensure a series of processes conforms to company standard sizes. The benefits in successfully adopting SPC technique cover both operational and financial (Grigg, 1999).

SPC is carried out using statistical tools contained in SPC (statistical process control) and SQC (statistical quality control) is a problem-solving technique used to monitor, control, analyze, manage, and improve products and processes using statistical methods. SQC is often referred to as statistical process control (Devani \& Wahyuni, 2017). By using SPC, it is possible to analyze and minimize deviations, evaluate process capabilities, and make connections between existing concepts and techniques to make process improvements. The main objective of the SPC is to reduce process variations or errors.

\section{Ishikawa Diagram (Fishbone)}

This causal diagram shows the relationship between cause and effect. It is also called a fishbone diagram because it looks like a fish skeleton or Ishikawa diagram because it was first introduced by Kaoru Ishikawa from Tokyo University in 1953 (Gasperz, 2000). Ishikawa diagram is a structured approach that allows a more detailed analysis to be carried out to find the causes of a problem, discrepancies, and existing gaps. 


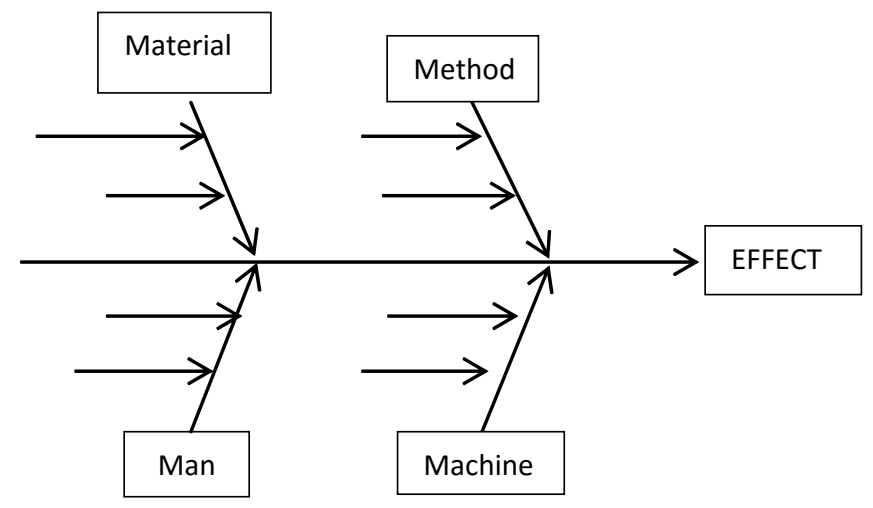

Figure 1. Cause and Effect Diagram

Source: (Heizer \& Render, 2015)

Another tool for identifying quality issues and point of inspection is cause-and-effect diagrams, also known as Ishikawa diagrams or fish-bone diagrams. Operations managers start out with four categories: materials, machines/tools, labor (man), and methods. These four Ms are causes. They provide a great checklist for initial analysis. The individual causes associated with each category are tied to separate bone diagrams along the branches, sometimes by means of a brainstorming process. For example, the branch of the method has problems caused by hand position, execution, point shooting, bending of the knee, and balance. When the fish-bone chart is developed systematically, possible quality issues and inspection points are highlighted. According to Nasution (2015), a cause and effect diagram is a structured approach that allows a more detailed analysis to be carried out in finding the causes of a problem, discrepancies, and gaps that occur.

\section{DATA ANALYSIS AND RESULTS}

To analyze data using statistical process control technique, the required data should include the causes of the defect product, defective types of products, the ongoing production process raw materials used, amount of production, and number of defective products. 


\section{Proportion of Defective Products}

The data that have been collected for 3 months for mica packaging craft product still indicated number of defective products as presented in table 1.

For mica packing craft products, the average percentage of defective products is $3.9 \%$. The highest occurred in the first week of January 2020, amounting to $8 \%$. In the first and second week of December 2019, the fourth week of January 2020, and the second and third week of February 2020. The types of defects found in this mica craft product are:

1) Break on zipper

2) Tear at the seam of the craft

3) Dirty

4) The tip of the mica breaks

5) Oblique stitch

Table 1.Percentage of defective mica packing craft products

\begin{tabular}{|c|c|c|c|c|}
\hline \multirow[t]{2}{*}{ Month } & \multirow[t]{2}{*}{ Week } & \multicolumn{3}{|c|}{ Mica packing Craft } \\
\hline & & $\begin{array}{l}\text { Production } \\
\text { (unit) }\end{array}$ & $\begin{array}{c}\text { Defective product } \\
\text { (unit) }\end{array}$ & $\begin{array}{c}\% \text { defective } \\
\text { product }\end{array}$ \\
\hline \multirow{4}{*}{$\begin{array}{l}\text { December } \\
2019\end{array}$} & I & 15 & 0 & 0.0 \\
\hline & II & 35 & 2 & 5.7 \\
\hline & III & 20 & 1 & 5.0 \\
\hline & IV & 11 & 0 & 0.0 \\
\hline \multirow{5}{*}{$\begin{array}{l}\text { January } \\
2020\end{array}$} & I & 50 & 4 & 8.0 \\
\hline & II & 35 & 1 & 2.9 \\
\hline & III & 40 & 1 & 2.5 \\
\hline & IV & 19 & 0 & 0.0 \\
\hline & I & 20 & 1 & 5.0 \\
\hline
\end{tabular}




\begin{tabular}{|l|c|c|c|c|}
\hline \multirow{2}{*}{2020} & II & 10 & 0 & 0.0 \\
\cline { 2 - 5 } & III & 10 & 0 & 0.0 \\
\cline { 2 - 5 } & IV & 17 & 1 & 5.9 \\
\hline TOTAL & & $\mathbf{2 8 2}$ & $\mathbf{1 1}$ & $\mathbf{3 . 9} *)$ \\
\hline
\end{tabular}

Source: Secondary data, processed (2020)

\section{Quality Control Performance with Proportion Charts}

Based on the data showed in table 1, further process is to identify the performance of product quality in proportion (proportion chart) with Standard Deviation which is calculated based on the formula:

$$
S t d_{P}=\sqrt{\frac{\bar{P}(1-\bar{P})}{n}}
$$

where

Std $_{\mathrm{P}}=$ Standard Deviation

$\bar{P} \quad=$ Total average that noted by Central Line (CL)

$\mathrm{N}=$ Total quantity of product

Standard deviation is tolerated at 0.5 times in order to achieve the goal of increasing quality control of products. This tolerance is applied to set the upper control limit (UCL) and the lower control limit (LCL). The results are as follows:

Table 2. Defective Products

\begin{tabular}{|l|l|}
\hline \multicolumn{1}{|c|}{ Description } & \multicolumn{1}{c|}{ Result } \\
\hline $\bar{P}$ & $11: 282=3.9 \%$ \\
\hline $\mathrm{N}$ & 282 \\
\hline
\end{tabular}




\begin{tabular}{|l|l|}
\hline Std $_{P}=\sqrt{\frac{\bar{P}(1-\bar{P})}{n}}$ & $3.6 \%$ \\
\hline UCL $=\bar{P}+(0.5$ X Std $)$ & $=5.7 \%$ \\
\hline LCL $=\bar{P}-(0.5$ X Std $)$ & $3.9 \%+(0.5$ X 3.6\%) $(0.5$ X 3.6\% $)$ \\
$=2.1 \%$
\end{tabular}

Source: Secondary data, processed (2020)

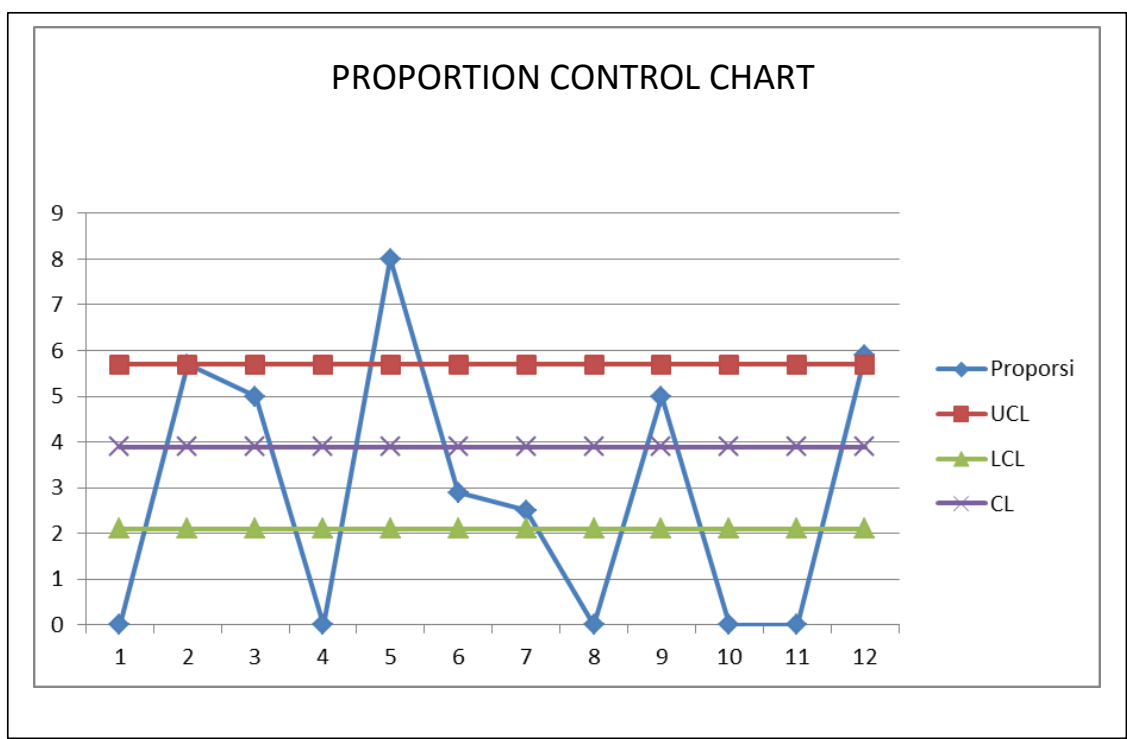

Figure 2. Proportion Control Chart 
Based on table 1 and 2, in general it can be seen that by applying the tighter control, the performance of quality control for mica packing craft products is already good (within control limits). Very good performance (under control limits) for mica packing crafts occurred in December, week I and IV, January week IV, and February week II and III. In this case the resulting product can be said to be perfect, because there is no defect at all.

Poor performance (above the control limit) for mica packing craft products occurred in January, week I and February week IV, with the percentage of defective products of $8.0 \%$ and $5.9 \%$, respectively. This performance is the main priority to be followed up. Before taking control measures for repairing, it needs to do a search for what causes the defective product to exceed this control limit.

\section{Causes Evaluation of Defective Products}

This evaluation was conducted using the Ishikawa diagram method based on 4 general factors as the main cause of the occurrence of defective products. The result is as follows:

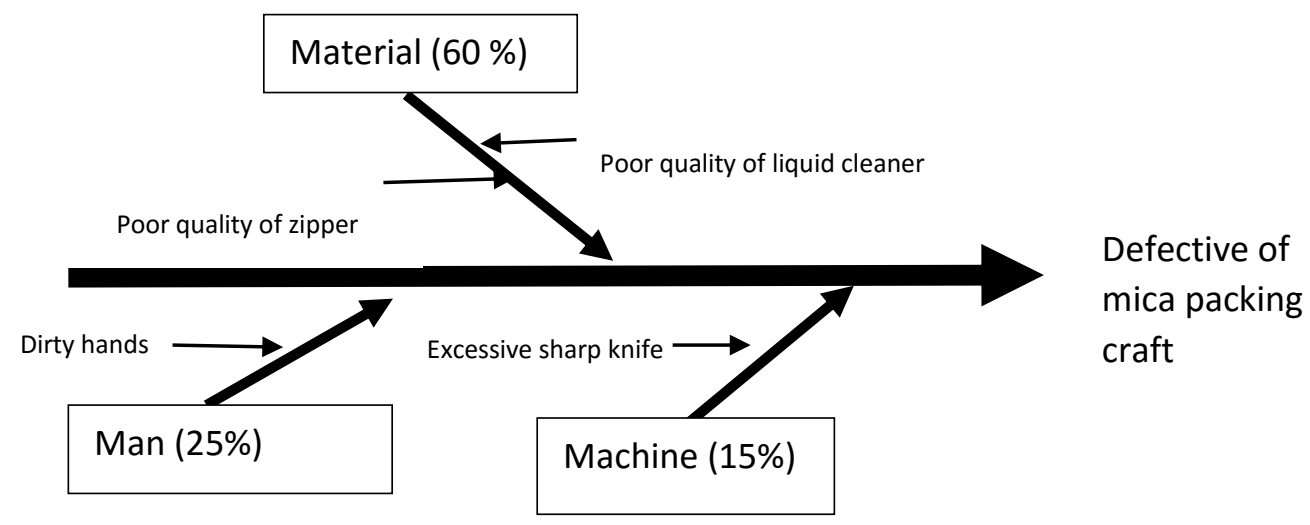

Figure 3. Fishbone Diagram of Defective Causes

Based on the figure 3 , the main factors that cause damage to mica packing craft products are material $(60 \%)$, human $(25 \%)$, and machines $(15 \%)$. Therefore, material factors are a priority for action to overcome. The two material-related causes were poor quality zipper 
and poor quality of liquid cleaner. These must be followed up to prevent the next defective product caused by the material factor.

\section{Corrective Actions to Resolve Defective Products}

For mica packing craft products, the main priority in order to overcome the causes of defective products is material factors, then human and machine factors. The following are the corrective actions planned using the $5 \mathrm{~W}$ and $1 \mathrm{H}$ methods for each type of causative factor based on these priorities:

Table 3. Corrective and Improvement Action of Material Causes Factor

\begin{tabular}{|c|c|c|}
\hline Type & $5 \mathrm{~W}+1 \mathrm{H}$ & Description \\
\hline $\begin{array}{c}\text { Main } \\
\text { Purpose }\end{array}$ & What & $\begin{array}{l}\text { All of material and raw material appropriate to the } \\
\text { required criteria. }\end{array}$ \\
\hline Reason & Why & $\begin{array}{l}\text { To prevent all of material and raw material that } \\
\text { will be processed in appropriate quantity, type, } \\
\text { and time. }\end{array}$ \\
\hline Location & Where & $\begin{array}{c}\text { At material warehouse, especially at the incoming } \\
\text { material division }\end{array}$ \\
\hline Sequence & When & Every material arrival from supplier. \\
\hline Person & Who & $\begin{array}{l}\text { Supervisor as person in charge and warehouse } \\
\text { staff who receive the material from supplier. }\end{array}$ \\
\hline Method & How & $\begin{array}{l}\text { Supervisor and staff control the material to ensure } \\
\text { the appropriate quantity and other characteristic } \\
\text { such as method to storage and condition of } \\
\text { storage media. }\end{array}$ \\
\hline
\end{tabular}

Source: Primary data, processed (2020) 
Table 4. Corrective and Improvement Action of Man Causes Factor

\begin{tabular}{|c|c|c|}
\hline Type & $5 \mathrm{~W}+1 \mathrm{H}$ & Description \\
\hline Murpose & What & To ensure all of mica packing craft is clean \\
\hline Reason & Why & To ensure all of staff' hands are clean, both at \\
staff at processing division and warehouse
\end{tabular}

Source: Primary data, processed (2020)

Table 5. Corrective and Improvement Action of Machine Causes Factor

\begin{tabular}{|c|c|c|}
\hline Type & $5 \mathrm{~W}+1 \mathrm{H}$ & Description \\
Purpose & What & Ensure the cutting machine run well. \\
\hline Reason & Why & Ensure the sharpness of knife on cutting machine \\
& are appropriate to cut the pattern of mica packing \\
Location & Where & Cuft. \\
\hline Sequence & When & Before cutting process of mica packing craft \\
& & \multicolumn{2}{c}{ pattern. } \\
\hline
\end{tabular}




\begin{tabular}{|c|c|c|}
\hline Person & Who & $\begin{array}{r}\text { Staff who operate cutting machine as person in } \\
\text { charge. }\end{array}$ \\
\hline Method & How & $\begin{array}{r}\text { Set up and check the sharpness on knife part of } \\
\text { cutting machine }\end{array}$ \\
\hline
\end{tabular}

Source: Primary data, processed (2020)

\section{CONCLUSION}

Although relatively tight controls (tolerance of 0.5 times the standard deviation) have been applied on the mica packing craft products, the performance of the proportion of defective products during the 3 months of production is still 3.6\% (above the standard set by the company of $3 \%)$. Apart from the fact that the characteristics of the production process are relatively more complicated than other products, most defects $(60 \%)$ are caused by dirty and unsuitable materials/materials.

To implement this result, the management should prepare production planning by assigning labor to run correction action as described in table 3, 4, and 5. Besides that, they have to prepare material supplier evaluation to reduce lack quality of the raw materials of mica products such as poor quality zipper and poor quality of liquid cleaner. Three main variables in supplier evaluation are general condition factor, service factor, and material factor.

Quality control performance on proportion chart shows that the enterprise has good performance (still within control limits) in some defective products. However, there are defective products that still need to be repaired because they have poor performance (outside the upper control limit / UCL). An investigation (evaluation) of defect causes on the defective products with poor performance that is carried out using the Ishikawa diagram results in human factors, material factors, method factors, and machine factors. Based on the causes, corrective 
actions are taken to overcome them according to the factors causing each type of defective product.

\section{REFERENCES}

Aditio, Hartono Soegiopranoto. (2020). “Perancangan Pengendalian Kualitas Produk Tas Dengan Metode Six Sigma Pada Perusahaan Souvenir Mega Promotion Semarang”. Faculty of Economics and Business, Soegijapranata Catholic University, Semarang. Ariesta, Daniel Suryonegoro. (2020). “Rancangan Pengendalian Kualitas Dengan Metode Six Sigma Pada Produk Bantal Cv. Mega Promotion Semarang”. Faculty of Economics and Business, Soegijapranata Catholic University, Semarang.

Assauri, Sofyan (2008), “Manajemen Produksi dan Operasi”, Publiser FE UI , Jakarta

Dendy, Jang Santoso. (2020). "Rancangan Pengendalian Kualitas Box Tutup Lubang Menggunakan Metode Six Sigma Pada Perusahaan Duz Creative Semarang". Faculty of Economics and Business, Soegijapranata Catholic University, Semarang.

Devani, V., \& Wahyuni, F. (2017). "Pengendalian Kualitas Kertas Dengan Menggunakan Statistical Process Control di Paper Machine 3". Jurnal Ilmiah Teknik Industri, 15(2), 87. https://doi.org/10.23917/jiti.v15i2.1504

Gaspersz V. (1998). "Total Quality Management". Third Edition, Gramedia Pustaka Utama, Jakarta.

Gaspersz, Vincent. (2000). "Manajemen Produktivitas Total". Gramedia Pustaka Utama, Jakarta.

Heizer, Jay; and Render, Barry. (2004). "Operations Management". Prentice Hall, International Edition.

Heizer, J., \& Render, B. (2015). "Manajemen Operasi" (11th ed.; P. S. Empat, Ed.). Pearson. 
Kho, Budi. (2018). "QC Seven Tools (Tujuh Alat Pengendalian Kualitas)" https://ilmumanajemenindustri.com/qc-seven-tools-tujuh-alat-pengendalian-kualitas. 28 Mei 2020

Kristiani, Kezia Nugroho. (2020). "Perancangan Pengendalian Kualitas Dengan Metode Six Sigma Pada Produk Paper Bag Studi Kasus Toko Souvenir Duz Creative Semarang". Faculty of Economics and Business, Soegijapranata Catholic University, Semarang..

Pande, Peter, Robert P.Neuman, R. R. C. (2000). "The Six Sigma Way", second edition, Publisher Andi.

Prawirosentono Suyadi. (2002). "Filosofi Baru Tentang Manajemen Mutu Terpadu". Bumi Aksara. Jakarta. 